\title{
Upaya Pencegahan Tindakan Plagiarisme untuk Meningkatkan Kualitas Penulisan Karya Tulis Ilmiah di Dalam Pembimbingan Tugas Akhir (Skripsi) Bagi Mahasiswa STIE Jambi
}

\author{
Laila Farhat \\ Sekolah Tinggi Ilmu Ekonomi Jambi \\ Correspondence email: lailafarhat75@yahoo.com
}

\begin{abstract}
This study aims to describe plagiarism in writing final assignments for students at STIE Jambi. This research was conducted at the Management Study Program at STIE Jambi. Data were collected through interviews and in-depth observations, and analyzed using explanatory approaches, specifically qualitative descriptive techniques. The findings obtained indicate that plagiarism in thesis writing includes duplication, which consists of (1) duplication of titles, (2) duplicate themes, (3) duplication of theories, (4) duplication of data, and (5) duplication of references. The process approach in writing this thesis can be used to prevent plagiarism. Such an approach consists of the following steps: return the draft thesis, show the original source, and cancel the thesis. This can be done by investigating, discussing, evaluating, and presenting the title and substance of the thesis. And the final results of finalizing the thesis are done by doing book printing, the printing of this book is intended as a reference material, input and knowledge / teaching material for the next student in scientific writing / thesis writing techniques to avoid plagiarism and increasing interest in writing scientific papers.
\end{abstract}

Keywords: Plagiarism, Thesis Writing, Book Printing.

\section{PENDAHULUAN}

Pada Perguruan Tinggi mahasiswa di latih untuk menghasilkan sebuah karya ilmiah untuk mengembangkan sebuah ilmu pengetahuan yang diperoleh selama mengikuti proses belajar mengajar. Definisi karya ilmiah menurut Djuroto \& Suprijadi (2005: 12) mengatakan bahwa, "karya ilmiah adalah suatu tulisan yang membahas suatu masalah, pembahasan itu dilakukan berdasarkan penyelidikan, pengamatan, pengumpulan data yang didapat dari sutau penelitian, baik penelitian lapangan, tes laboratorium ataupun kajian pustaka. Maka dalam memaparkan dan menganalisis datanya harus di dasarkan pemikiran ilmiah". Dari pengertian karya ilmiah tersebut dapat disimpulkan bahwa karya ilmiah merupakan hasil penelitian ilmiah yang dilaporkan atau diterbitkan dalam bentuk tertulis oleh seseorang atau beberapa orang yang hasilnya dapat dipertanggungjawabkan kebenarannya. Diperguruan tinggi khususnya pada jenjang Strata Satu (S-1), mahasiswa dilatih untuk menghasilkan sebuah karya ilmiah yang disebut skripsi. Skripsi merupakan sebuah karya ilmiah yang dibuat oleh mahasiswa sebagai syarat kelulusan pada jenjang pendidikan strata satu (S-1) yang di dalamnya mengandung sebuah filosofis dari penelitian yang objektif terhadap suatu permasalahan disertai dengan tinjauan analisis berdasarkan metodologi penelitian tertentu yang digunakan untuk memecahkan permasalahan tersebut secara teoritis.

Salah satu nilai tertinggi karya tulis adalah orisinalitas atau keaslian. Pernyataan ini mengandung makna, bahwa sebuah karya tulis harus memiliki nilai kualitas dalam hal keaslian, objektivitas, dan kejujuran. Makna 'asli' bukan berarti semua ide, gagasan, dan pengetahuan yang disampaikan seseorang dalam karya tulisnya tersebut, semuanya berasal dari dirinya sendiri. Melainkan lebih pada kejujuran dalam mengemukakan tulisannya. Apabila sebuah kata, kalimat, paragraf, ide, gagasan, atau pendapat yang dimunculkan dalam tulisanya tersebut adalah milik orang lain (atau dari sumber lain), maka etika ilmiahnya adalah: mencantumkan sumber dengan jujur dan objektif di mana ia mendapatkan kutipan tersebut. Kasuskasus duplikasi, penjiplakan, atau plagiarisme muncul, justru karena nilai kejujuran dan objektivitas ini dilanggar atau diabaikan. Plagiarisme merupakan salah satu tindak kejahatan akademik karena didalamnya terdapat unsur pencurian berupa pencurian ide-ide dan gagasan tanpa mencantumkan sumber aslinya. Hal tersebut sangatlah bertentangan dengan prinsip pendidikan yang ingin menciptakan sumber daya manusia yang berilmu dan berakhlak mulia. Di dunia akademik, kadang plagiat terjadi oleh karena beban yang diterima peserta didik amat berlebihan (Herqutanto, 2013). Selama proses pembelajaran berjalan, mahasiswa dituntut untuk mampu mengerjakan berbagai macam tugas secara maksimal, tentu ada konsekuensi tersendiri jika mahasiswa tidak dapat melakukannya. Bisa jadi mahasiswa tersebut mendapatkan nilai yang tidak memuaskan sehingga mempengaruhi nilai UAS dan mengharuskan mahasiswa tersebut mengulang 
pada semester berikutnya. Selain itu sistem di perguruan tinggi juga mensyaratkan mahasiswa untuk menulis tugas akhir yang hasilnya akan menentukan kelayakan mahasiswa tersebut untuk meraih gelar Sarjana Strata 1, Strata 2, ataupun Strata 3. Plagiarisme atau sering disebut plagiat adalah penjiplakan atau pengambilan karangan, pendapat, dan sebagainya dari orang lain dan menjadikannya seolah-olah karangan dan pendapat sendiri (Alsasian, 2006). Plagiat dapat dianggap sebagai tindak pidana karena dianggap mencuri hak cipta orang lain dan melanggar undang-undang tentang hak cipta. Praktek plagiat juga dapat menimbulkan konflik antar sesama apabila terdapat lebih dari satu orang mengakui satu karya. Di dunia pendidikan, rentan terjadi praktek plagiarisme. Misalnya dalam hal pembuatan Tugas Akhir, sering terjadi kemiripan antar Tugas Akhir. Untuk mendeteksi kemiripan tersebut, banyak Perguruan Tinggi/Universitas yang masih melakukannya secara manual sehingga menghabiskan waktu yang lama juga tenaga yang ekstra (Hari, 2003).

Watak dan sikap yang termuat dalam butir etika akademik ilmiah yang harus dijunjung tinggi adalah jujur dan objektif dalam kehidupan ilmiah (Kode Etik Mahasiswa dan Dosen STIE Jambi, 2015). Salah satu kegiatan atau aktivitas terkait dengan nilai kejujuran dalam kehidupan ilmiah adalah: sikap dalam penulisan karya tulis. Dalam konteks penulisan dan penelitian ini, karya tulis yang langsung terkait dengan mahasiswa adalah Tugas Akhir Skripsi (TAS). Karya tulis inilah yang perlu mendapat tekanan dan perhatian serius. Persoalan ini sangat signifikan dikelola dan diteliti terkait dengan banyaknya gejala plagiarisme yang terjadi di dalamnya. Tugas akhir skripsi dapat dianggap sebagai karya tulis mahasiswa yang paling besar porsinya secara ilmiah. Penyelesaiannya membutuhkan sejumlah kemampuan, energi, pemikiran, tenaga, bahkan dana yang relatif banyak. Oleh karena itu, tugas akhir skripsi sering menjadi kebanggaan mahasiswa karena dianggap paling berbobot. Penyelesaian tugas akhir ini sering menjadi pertaruhan studi mahasiswa. Banyak mahasiswa yang gugur/DO (droup out), atau terpaksa alih jenjang karena gagal menyelesaikan tugas akhir ini. Sebaliknya, bagi mahasiswa yang mampu menyelesaikan tugas skhir (skripsi) sesuai tepat waktu, atau apalagi, kurang dari waktu yang telah ditentukan (artinya selesai lebih cepat), dan berkualitas, akan menjadi kenangan dan kebanggaan yang tidak mudah terlupakan begitu saja. Banyak pihak, misalnya jurusan, dosen PA, dosen pembimbing, dosen penguji, orang tua, keluarga, teman-teman, akan memuji dan membanggakanya.

Sesuai dengan buku Panduan Penulisan Skripsi yang diterbitkan oleh STIE Jambi (PPS, 2018), sebuah karya tulis penelitian bentuk skripsi, diformatkan mencantumkan relevansi dengan karya penelitian orang lain terdahulu. Namun, sudah menjadi rahasia umum, bahwa cara ini justru menggiring mahasiswa untuk melakukan duplikasi atau plagiarisme. Sadar atau tidak, cara mengutip yang dilakukan telah mendekatkan karya tulis mereka pada karya tulis orang lain. Dari sinilah antara lain gejala plagiarisme muncul. Plagiarisme, atau jiplakan (Moeliono, ed. KBBI, 1988: 690) adalah pengambilan karya orang lain, dan dipublikasikan sebagai karya miliknya. Senyatanya, terutama di dunia ilmiah, pengambilan tulisan atau mengutip karya orang lain tersebut, kadang-kadang justru dianjurkan namun dengan aturan dan norma yang telah berlaku dan disepakati secara luas di dunia akademik. Persoalannya, seberapa besar kadar pengambilan kutipan, bagaimana cara mengutip, dan apakah pihak pengutip menyertakan sumber kutipannya atau tidak; adalah sesuatu yang sulit ditelusur. Sementara itu, aksi plagiarisme terus berjalan, tidak ada peraturan yang mampu menghentikannya. Buktinya, gejala ini sampai sekarang terus terjadi. Tindak-tindak plagiarisme karya tulis ilmiah satu persatu bermunculan dan terpublikasi secara luas, yang menyebabkan tercorengnya nilai kejujuran dan objektivitas pelaku pendidikan (terutama) di perguruan tinggi. Keberadaan aturan, etika, atau panduan penulisan tugas akhir skripsi, tesis, atau disertasi di Perguruan Tinggi tampaknya bukan jaminan untuk menghentikan perbuatan jiplak-menjiplak ini. Berkali- kali dunia kampus digegerkan oleh ulah oknum mahasiswa atau dosen yang mempublikasikan karya tulis penelitiannya, yang akhirnya terbukti karya tersebut hasil plagiarisme. Sebagai contoh, kasus yang terjadi di salah satu Perguruan Tinggi terkemuka di Yogyakarta, seorang promovendus (kandidat doktor), terpaksa dibatalkan gelar doktornya oleh pihak Senat Universitas, setelah terbukti dengan sah, bahwa karyanya sebagian besar adalah hasil plagiarisme (KR, 12/04/2005). Pada kesempatan yang sama dia juga dilarang tampil dalam berbagai kesempatan presentasi ilmiah dan sejumlah penelitian. Fakta dan fenomena ini benar-benar memprihatinkan. Sebagian orang bahkan menyebut plagiarisme adalah tragedi moral di dunia akademik. yang akhirnya ternyata keberadaan aturan, etika, atau panduan penulisan tugas akhir skripsi, tesis, atau 
Laila Farhat, Upaya Pencegahan Tindakan Plagiarisme untuk Meningkatkan Kualitas Penulisan Karya Tulis Ilmiah di Dalam Pembimbingan Tugas Akhir (Skripsi) Bagi Mahasiswa STIE Jambi

disertasi di Perguruan Tinggi tampaknya bukan jaminan untuk menghentikan perbuatan jiplak menjiplak ini. Selain itu penelitian yang dilakukan oleh Mulyana pada tahun 2010 pada mahasiswa jurusan Pendidikan Bahasa Daerah dan Fakultas Bahasa dan Seni Universitas Negeri Yogyakarta yang sedang mengerjakan tugas akhir juga ditemukan beberapa tindak plagiat, jenis-jenis plagiarisme yang dilakukan sangat bervariasi, diantaranya adalah kesamaan judul, substansi isi penelitian, teori yang di gunakan, dan referensi yang di jadikan acuan.

Plagiarisme karya tulis, secara formal, termasuk perbuatan melawan hukum. Gejala yang terjadi adalah tindak pidana pencurian atas hak kepemilikan yang dimiliki oleh orang lain. Apabila sang pemilik hak mengetahui bahwa karya ciptanya dicuri, dan dirinya tidak bisa menerima perbuatan tersebut maka secara hukum kasus ini dapat di pidanakan. Orang yang mencuri, menjiplak karya orang lain dapat dikenai hukuman sesuai dengan keputusan hukum yang adil; misalnya, sanksi administrasi, didenda, dicabut karyanya, dibatalkan gelarnya, atau dipenjara. Berkembangnya tindak-tindak plagiarisme terutama di Perguruan Tinggi harus secepatnya diantisipasi karena bertentangan dengan semangat pengembangan watak atau karakter (character development) civitas akademika di dunia pendidikan (Astin, 1993:5). Memang, sejumlah persoalan terminologis muncul seiring dengan pemahaman plagiarisme karya tulis ilmiah. Misalnya, bagaimana mengukur atau menyebut bahwa tulisan seseorang dikatakan menjiplak tulisan orang lain. Apa saja indikator yang dapat digunakan untuk mendefinisikan dengan tepat bahwa seseorang telah melakukan perbuatan melawan hukum yang disebut plagiarisme. Seberapa banyak (berapa presentasenya) seseorang boleh melakukan pengutipan dari sumber lain. Padahal, kenyataanya, karya tulis baru disebut "ilmiah" justru apabila ada kutipan pendapat orang lain. Menuliskan sumber berarti, mengidentifikasi pencipta suatu ciptaan yang kita gunakan sebagai sumber kutipan kita: judul ciptaan, nama pencipta, penerbit, dan sebagainya, harus dengan jelas diungkapkan dengan cara yang sesuai dengan bentuk dari perbanyakan atau eksploitasi (Panduan HKI, 2006:34). Barangkali cara ini dianggap tepat dan ampuh menjadi "pagar penjaga" terjadinya tindak-tindak plagiarisme dalam penulisan karya tugas akhir mahasiswa di lingkungan akademiknya.

Berdasarkan catatan, kasus-kasus plagiarisme di dunia pendidikan (termasuk di perguruan tinggi), terjadi karena lemahnya aturan, dan kurangnya kesadaran moral ilmiah seorang penulis. Jadi, salah satu indikator utama terjadinya plagiarisme adalah pengambilan kutipan (entah sedikit atau banyak), tetapi si pengutip tidak menyebutkan sumber kutipannya. Sehingga seolah-olah apa yang ditulisnya adalah miliknya sendiri. Di STIE Jambi aturan formal yang dilansir STIE Jambi adalah "pengambilan dan cara mengutip (data, pendapat, hasil penelitian) orang lain atau pustaka yang bukan karangannya sendiri, wajib menyertakan sumber asli kutipannya (Panduan PPS, 2018). Menyertakan sumber asli berarti pengutip harus mengidentifikasi secara eksplisit sumber tulisan: nama penulis/ pencipta, penerbit, tahun terbit/publikasi, halaman, dan seterusnya. Sebenarnya, secara formal, mahasiswa diwajibkan menulis di halaman pernyataan bahwa apa yang ditulisnya adalah benar-benar karya sendiri. Setelah menuliskan identitas dirinya secara jelas penulis tugas akhir harus menyatakan ungkapan formal sebagai berikut. Menyatakan bahwa karya ilmiah ini adalah hasil pekerjaan saya sendiri. Sepanjang pengetahuan saya, karya ilmiah ini tidak berisi materi yang ditulis oleh orang lain, kecuali bagian-bagian tertentu yang saya ambil sebagai acuan dengan mengikuti tatacara dan etika penulisan karya ilmiah yang lazim. Apabila ternyata terbukti bahwa pernyataan ini tidak benar, sepenuhnya menjadi tanggungjawab saya.(PPS, Lampiran, 2018).

Persoalnnya apakah tulisan pernyataan tersebut mampu menjaga kejujuran mahasiswa, mampukah penyataan itu menjamin tidak terjadinya gejala plagiarism dalam penulisan tugas akhir? Bagaimana sebenarnya bentuk-bentuk plagiarism skripsi ini bisa terjadi ? inilah sejumla maka bukan tidak mungkin jenis-jenis penelitian mahasiswa akanh persoalan yang akan dikaji dalam penelitian ini. Hasil akhir yang di harapkan dari upaya ini antara lain adalah terciptanya budaya penulisan karya ilmiah mahasiswa yang objektif, orisinil dan bertanggung jawabpada gilirannya apa bila pola ini tercipta dan terkondisi maka bukan tidak mungkin jenis-jenis penelitian mahasiswa akan semakin berkualitas dan bervariasi. Usaha ke arah pembenahan diri (self-renewal) perlu diaplikasikan (Suyata, 1998:3). Salah satu cara aplikatif dan efektif yang dapat mengurangi plagiarisme dalam penulisan Tugas akhir adalah dengan menerapkan 'pendekatan proses' secara jelas, mantap, dan berkelanjutan. Pendekatan proses (PP) atau yang sering disebut pendekatan keterampilan proses (PKP) adalah seluruh irama dan tindakan dalam proses 
belajar mengajar yang dapat menciptakan kondisi belajar siswa aktif. PP ini disandarkan juga pada pengolahan penelitian Sudaryanto (2000) dengan penyesuaian tertentu dengan tujuan mengantisipasi adanya gejala plagiarisme atau duplikasi karya skripsi mahasiswa. Penjabaran dan tahapan PP tersebut adalah sebagai berikut:

a) pramenulis (tahap ini mahasiswa diberi tugas mencari topik skripsi, menyusun kerangka karangan, mencari bahan-bahan acuan, dan menyiapkan segala sesuatu yang dapat menunjang kerja ilmiah tersebut);

b) (2) penyusunan draf (tahap ini mahasiswa harus sudah selesai menyiapkan dan menyusun draf untuk proposal tugas akhir;

c) revisi (tahap perbaikan dan pembenahan draf setelah dikoreksi oleh dosen pembimbing dan mahasiswa lain (sebagai koreksi silang dan antisipasi gejala plagiarisme);

d) editing (tahap penyuntingan dilakukan dengan cara membenahi draf yang telah dikoreksi; dan

e) sharing (tahap berbagi adalah langkah publikasi terbatas yang dilakukan tim skripsi untuk menyebarluaskan draf yang telah diajukan mahasiwa kepada lingkup terbatas (komunitas dosen, dan kelas mahasiswa) untuk dibaca, dikoreksi, dan didiskusikan.

Etika menulis karangan ilmiah sebenarnya masuk dalam ranah moral akademis. Oleh karena itu, aturannya sering hanya bersifat formalitas saja. Sebut saja misalnya, pada setiap karangan ilmiah TAS wajib disertakan halaman pernyataan yang isinya menyatakan bahwa, karya ilmiah yang ditulisnya adalah benar-benar karya sendiri dan bukan hasil jiplakan karya orang lain (Panduan PPS, 2018). Semangat yang melandasi pernyataan ini adalah menjunjung tinggi nilai kejujuran dan orisinalitas sebuah karya tulis yang menjadi hak milik seseorang. Sudut pandangnya bisa dilihat dari dua sisi: (1) dari penulis sendiri, dan (2) dari orang lain. Sudut pandang penulis sendiri sebagai penulis, dianjurkan untuk menjunjung tinggi nilai kejujuran, dan keaslian sebuah karya. Normatifnya ialah, kalau bukan milik sendiri sudah seharusnya tidak dikatakan sebagai miliknya. Apabila kaidah normatif ini dilanggar, maka telah melakukan perbuatan pengambilan hak milik (cipta) orang lain. Hal ini jelas termasuk perbuatan pidana. Dilihat dari sudut orang lain, pengambilan hak cipta milik orang lain jelas akan merugikan pihak lain secara ekonomis, moral, dan intelektual. Modus tindak plagiarisme karya tulis ilmiah pada umumnya terdiri atas: (1) mengcopy karya orang lain; (2) membonceng karya orang lain; (3) mengubah karya orang lain; (4) dibuatkan orang lain; dan (5) membeli karya orang lain. Modus seperti ini jelas telah menghancurkan nilai penghargaan atas hak cipta karya orang lain, dan lebih dari itu juga telah merendahkan nilai kejujuran dan derajat keilmiahan diri sendiri.

Sebenarnya, aturan menyangkut sanksi bagi pelaku tindak plagiarisme sudah cukup jelas. Berdasarkan UU No.20/2003, tersebut bahwa sanksi atas tindak plagiarisme dalam persoalan karya tulis sebagai berikut: (1) lulusan PT yang karya ilmiahnya digunakan untuk memperoleh gelar akademik, profesi, atau vokasi, terbukti merupakan jiplakan, dicabut gelarnya (pasal 25 ayat 2); (2) Lulusan yang tersebut pada pasal 25 ayat 2 dipidana dengan pidana penjara paling lama dua tahun, dan atau pidana denda paling banyak Rp. 200.000.000,- (dua ratus juta rupiah). (Yayasan Rumah Ilmu Indonesia.EJournal/2010/ 04/04). Apapun hukum dan ketentuan menyangkut hak cipta dan pelanggarannya, apabila tidak diindahkan maka hasilnya hanya sia-sia belaka. Terus terang fakta menunjukkan, bahwa aturan formal tersebut tampaknya belum mampu menutup kasus-kasus menyangkut plagiarisme dalam karya tulis ilmiah. Azas etika universal belum dihargai secara maksimal (Zuchdi, 1994:9). Salah satu muara persoalan ialah: nilai kejujuran. Oleh karena itu, aspek inilah yang mestinya menjadi perhatian utama dalam proses character building (pembangunan jati diri dan watak) insan di dunia akademik.

\section{METODE}

Penelitian ini menggunakan pemecahan masalah dengan pendekatan proses yang dilakukan secara eksploratif, yaitu penelitian yang mengedepankan pengungkapan kasus-kasus yang terjadi dalam lingkup tertentu, dan dalam persoalan tertentu. Pengungkapannya dilakukan secara komprehensif, integratif, mendalam dan berkelanjutan. Model ini digunakan secara langsung karena dapat menyelesaikan masalah secara praktis. Waktu dan tempat penelitian dilakukan di Prodi Manajemen STIE Jambi, sepanjang tahun 2019, tepatnya dimulai sejak bulan April - Agustus 2019. 
Draf proposal tugas akhir skripsi yang masuk di jurusan di dokumentasi dan diklasifikasi. Selanjutnya sejumlah persoalan yang muncul dicermati untuk kepentingan deskriptif analitis. Subjek penelitian adalah draf proposal tugas akhir skripsi, sementara objeknya adalah jenis-jenis duplikasi tugas akhir yang di indikasikan termasuk plagiarisme hak cipta karya tulis ilmiah. Topik-topik atau materi tugas akhir yang terindikasi plagiarisme dijadikan data penelitian untuk mendapatkan gambaran kasus-kasus apa saja yang melekat dalam persoalan ini.

Data dikumpulkan dengan teknik dokumentasi dan wawancara terbingkai. Artinya, data dikumpulkan dari sejumlah draf pengajuan tugas akhir yang masuk ke program studi (data ini disimpan/didokumentasi dengan rapi oleh petugas administrasi jurusan, dan kemudian diserahkan kepada koordinator tim penyelesaian tugas akhir di Prodi Manajemen STIE Jambi). Wawancara juga dilakukan untuk menjaring sejumlah motif, dan gagasan mahasiswa tentang topik yang akan diajukannya. Data materi yang telah diklasifikasi sesuai dengan persoalan, kemudian dianalisis secara deskriptif kualitatif. Metode deskriptif digunakan untuk mengidentifikasi topik dan substansi tugas akhir yang diajukan mahasiswa. Langkahnya adalah menelaah seluruh data yang telah tersedia dari berbagai sumber, yaitu dari wawancara, observasi, catatan, dokumen, dan sejumlah sumber lainnya yang terkait. Sejumlah kemiripan karya yang berhasil ditemukan, selanjutnya dikenakan pendekatan dengan menggunakan teori Elliot (1990), yaitu: telaah, diagnosis, perencanaan, pelaksanaan, pemantauan, dan evaluasi. Pemeriksaan keabsahan data dilakukan dengan teknik triangulasi, yaitu pemeriksaan dari sejumlah sumber terkait untuk mendapat validitas dan reliabilitas data. Antara lain, dengan pemeriksaan sumber, wawancara, dan konsultasi antar ahli (sesama dosen pembimbing) tugas akhir skripsi. Setelah langkah tersebut di lakukan maka dapat di buat kesimpulan dan selanjutnya di lakukan pencetakan buku sebagai bahan hasil dari peneltian dan juga di jadikan bahan ajar yang berguna bagi mahasiswa selanjutnya untuk bahan acuan dan bahan referensi agar terhindarnya tindak plagiarisme dan dengan pencetakan buku tersebut berguna sebagai bahan untuk meningkatkan minat dalam menulis karya ilmiah yang bermutu.

\section{HASIL}

Berdasarkan alur penelitian dan pendekatan proses yang telah dilakukan ditemukan sejumlah proposal atau karya skripsi yang dikembalikan dan atau dibatalkan karena alasan mendekati plagiarisme. Artinya, beberapa proposal dan atau skripsi memiliki kemiripan atau duplikasi dalam hal judul, topik, tema, data, dan kajian teori. Meskipun tidak termasuk dalam metode penelitian, namun berdasarkan pemantauan sebelumnya, kasus plagiarisme relatif memiliki kemiripan satu dengan yang lain di lingkungan Prodi STIE Jambi, yaitu duplikasi karya atau peniruan karya tulis mahasiswa lain. Duplikasi atau peniruan karya yang ditemukan di Prodi Manajemen STIE Jambi antara lain adalah: duplikasi judul, duplikasi substansi, duplikasi kajian teori, duplikasi data, dan duplikasi referensi. Sejumlah faktor yang menyebabkan terjadinya gejala plagiarisme tersebut antara lain adalah: (1) faktor internal (berkaitan dengan watak, karakter); dan (2) faktor eksternal (berkaitan dengan kondisi, kesempatan).

Tabel 1.

Jenis Plagiarisme Tugas Akhir Skripsi Mahasiswa

\begin{tabular}{lll}
\hline Kasus & Jenis Plagiarisme & Tindakan Pengendalian \\
\hline \multirow{3}{*}{ Plagiarisme } & 1. Duplikasi Judul & \\
Skripsi & 2. Duplikasi Substansi & Mengembalikan usulan tugas akhir skripsi dan atau merevisi. \\
& 3. Duplikasi Teori & Mengharuskan pengkutipan sumber data primer. \\
& 4. Duplikasi Data & Membatalkan karya tulis \\
& 5. Duplikasi Referensi & \\
\hline
\end{tabular}

Plagiarisme berbentuk duplikasi judul. Duplikasi judul menyangkut kesamaan atau kemiripan judul. Sejumlah tugas akhir yang diajukan ke prodi atau dikonsultasikan ke calon pembimbing terindikasi memiliki kesamaan, sehingga perlu segera diantisipasi. Misalnya: Analisis bauran pemasaran pada PT. Gudang Garam Jambi; Analisis Price, Product, Place dan Promosi pada PT. Primatama Jambi. Duplikasi semacam ini tampak jelas hanya berbeda dalam hal pemilihan kosa kata. Yaitu antara "bauran 
pemasaran" dengan "price, produk, place dan promosi”. Untuk mengantisipasi munculnya gejala plagiarisme lebih lanjut, draf pertama atau yang terakhir diajukan dikembalikan kepada mahasiswa untuk diperbaiki atau diganti dengan judul atau topik lain. Tindak pencegahan dengan cara persuasif, yaitu "mengembalikan usulan" ditekankan dengan dua pilihan: ganti atau revisi. Pada tahap awal, mahasiswa akan segera menyadari kelalaiannya melakukan tindak duplikasi, yang kemungkinan dilakukan dengan sadar atau tidak.

Plagiarisme berbentuk duplikasi substansi. Bentuk ini maksudnya adalah kesamaan atau kemiripan dalam hal isi dan substansi yang diteliti. Duplikasi isi, pada umumnya terjadi karena karya tersebut menggunakan objek kajian yang sama. Misalnya: Penelitian Pada PT. Asuransi Sinar Mas dan Penelitian Pada PT. Asuransi Manulife. Kesamaan secara substansi dapat dilihat dalam hal kajian "Penelitian pada". Perbedaannya hanya terletak pada seting penelitian, dan spesifikasi kajian yang dilakukan. Duplikasi isi akan mengurangi orisinalitas peneliti dalam mengeksplorasi data penelitian. Artinya, peneliti tidak akan banyak bekerja karena sudah dituntun oleh penelitian terdahulu yang mirip. Plagiarisme berbentuk duplikasi teori. Kasus ini tampaknya paling banyak ditemukan dalam penulisan tugas akhir mahasiswa Prodi Manajemen STIE Jambi. pengajuan tugas akhir skripsi biasanya menunjukkan gejala musiman topik. Misalnya, pada tahun ini, banyak mahasiswa yang menulis bidang Pemasaran, tahun berikutnya mayoritas menulis SDM, tahun berikutnya lagi, menulis Keuangan, hampir demikian seterusnya. Akibatnya, setiap musim (angkatan pengajuan tugas akhir), bentuk kajiannya menunjukkan gejala duplikasi teori. Sebagaimana diketahui, kajian teori yang umumnya ditulis pada BAB II (Panduan PPS STIE Jambi, 2009) yang mengambil topik atau bidang penelitian yang sama, banyak yang menunjukkan kesamaan teori antara skripsi yang satu dengan lainnya. Kajian penelitian skripsi di Prodi Manajemen dipilah menjadi tiga bidang, yaitu Pemasaran, Sumber Daya Manusia, dan Keuangan Kajian dalam bidang dan spesialisasi yang sama, rentan terjadi duplikasi, misalnya: Pengaruh gaya kepemimpinan terhadap kinerja karyawan; Analisis kepemimpinan dan motivasi terhadap kinerja ASN; dan Analisis pengaruh gaya kepemimpinan otoriter terhadap kepuasan kerja karyawan.

Kajian teori biasanya diletakkan di bagian kedua (Bab II) sesuai dengan format penulisan skripsi (PPS, 2018). Ketiga draf judul di atas semuanya bermuara pada bidang SDM. Data penelitian menunjukkan pada BAB II ketiga usulan penelitian tersebut nyaris sama. Kesamaan itu dimulai dengan penyusunan urutan teori: a) pengertian kepemimpinan; b) variasi bahasa; dan c) register, dengan sejumlah subjudul yang duplikatif. Hal sama terjadi juga dalam bidang Pemasaran. Misalnya: Pengaruh kualitas produk dan promosi terhadap penjualan barang; dan Pengaruh strategi promosi melalui sosial media terhadap volume penjualan.

Bisa dipastikan kajian teori kedua skripsi tersebut sama (salah satu menjadi duplikasi lainnya). Kasus semacam ini dapat dicegah dengan upaya mewajibkan penulis tugas akhir skripsi menyebutkan, menyertakan, dan kalau perlu membawa secara fisik sumber primer kutipannya. Sementara itu, plagiarisme berbentuk duplikasi referensi. Sering ditemukan pada bagian daftar pustaka (referensi). Terbukti bahwa mahasiswa hanya mengkopi daftar pustaka skripsi lain yang memiliki kesamaan substansi. Bukti bahwa mahasiswa melakukan duplikasi referensi karena mereka pada umumnya tidak menemukan dan membaca sendiri pustaka yang dicantumkan pada bagian daftar pustaka skripsinya. Pada bagian lain, persoalan kutip-mengutip referensi ini bahkan juga tejadi gejala penyandaran referensi palsu. Bentuk ini cukup meresahkan dunia akademik, karena mahasiswa menuliskan sebuah sumber (ide, gagasan, pendapat, lainnya), sebagai milik orang lain, tetapi ternyata miliknya sendiri. Atau bahkan sebaliknya, dan ini yang paling berbahaya, mahasiswa menulis atau mengutip sebuah referensi (baik sedikit maupun banyak) tanpa menyertakan dari mana sumbernya. Inilah yang disebut plagiarisme karya tulis. Upaya pencegahan yang dilakukan adalah "membatalkan tugas akhir skripsi" nya. Solusinya: "merevisi substansi secara total, atau membatalkan atau mengganti karyanya dengan topik lain". Inilah upaya paling berat yang dilakukan untuk mengantisipasi terjadinya tindak plagiarisme tugas akhir skripsi.

Berdasarkan diagnosis penelitian yang berupa pantauan dan perlakukan penelitian yang diterapkan, ditemukan sejumlah hambatan yang dialami mahasiswa dalam mengajukan dan menulis tugas akhir skripsi. Secara umum, hambatan yang menjadi faktor penyebab terjadinya bentuk plagiarisme tugas akhir adalah: faktor internal dan eksternal. Kedua faktor itu dapat diuraikan menjadi beberapa faktor, yaitu: (1) motivasi diri yang rendah; (2) kurang memahaminya materi yang ditulisnya 
sendiri; (3) kemampuan menulis yang rendah; (4) kurangnya komunikasi dengan pembimbing skripsi; (5) ingin cepat menyeselesaikan dan mencari jalan pintas secepatnya; dan (6) persoalan pribadi masing-masing mahasiswa. Sejumlah hambatan di atas, tampaknya terakumulasi menjadi satu hambatan besar yang dialami mahasiswa sejak awal mengajukan proposal skripsi. Akibatnya, topik yang diajukan mahasiswa terkesan 'asal jadi', 'cari yang gampang' dan 'pokoknya mengajukan'. Tim koordinasi penyelesaian tugas akhir Prodi Manajemen sudah menginventarisasi hambatan dan bagaimana solusinya.

Hambatan internal bermuara pada kurangnya semangat dan motivasi mahasiswa untuk menulis tugas akhir dengan mutu yang memadai. Akibatnya apa yang ditulis atau diajukan hanya asal mengajukan. Cara untuk mengatasinya adalah dengan menumbuhkan semangat dan kemampuan mahasiswa, sambil terus menerus meyakinkan bahwa mahasiswa sebenarnya mampu menulis dengan tingkat orisinalitas yang tinggi dan mutu yang mamadai. Sementara itu, hambatan atau aspek yang bersifat teknis, misalnya kurangnya kemampuan di bidang kebahasaan (misalnya, keterampilan menyusun kalimat, paragraf) dapat diantisipasi dengan banyak latihan menulis, membaca karya penelitian lain, dan memahami benar panduan penulisan tugas akhir. Hambatan eksternal lain, semacam kesibukan berorganisasi, bekerja, dan kurangnya komunikasi dengan pembimbing bisa diatasi dengan pendekatan personal, pembuatan jadwal waktu secara ketat dan mengerjakan tugas penulisan secara proporsional. Selanjutnya, plagiarisme dalam penulisan tugas akhir skripsi terutama di jurusan Prodi Manajemen dapat dikurangi dengan langkah-langkah sesuai dengan pendekatan proses sebagaimana telah diuraikan pada tahap penemuan gejala plagiarisme tugas akhir yang ditulis mahasiswa. Penanganan minimal yang dapat dilakukan adalah:

Mengidentifikasi gejala duplikasi tugas akhir;

Membahas gejala duplikasi tersebut dengan anggota tim Tugas akhisr skripsi Prodi;

Membicarakan gejala duplikasi tersebut dengan mahasiswa yang bersangkutan;

Mengembalikan draf proposal dengan menunjukkan kemiripannya dengan karya lain yang sudah ada sebelumnya; dan

- Pada tindakan selanjutnya, mahasiswa harus memperbaiki draf dan atau mengganti karya tulisnya agar tidak terkena sanksi akademis yang menjadi kebijakan institusi.

Tahapan solusi dan pencegahan tindak plagiarisme dalam penelitian ini baru pada tingkat antisipasi. Penerapan pendekatan proses bertujuan melatih mahasiswa memahami gejala plagiarisme dan selanjutnya menjauhi segala bentuk plagiarisme dalam karya tulis ilmiahnya. Terus terang, inti persoalannya kadang-kadang tidak atau belum mampu ditangani secara teknis administratif. Plagiarisme hampir pasti menyangkut aspek moral seseorang. Oleh karena itu, penanganan dalam penelitian ini untuk sementara hanya bersifat pembinaan, pengendalian dan pencegahan.

\section{SIMPULAN}

Gejala plagiarisme tugas akhir yang dilakukan mahasiswa Prodi Manajemen STIE Jambi pada umumnya masih pada taraf duplikasi, yaitu bentuk-bentuk peniruan, penjiplakan karya orang lain dengan persentase duplikasi yang bervariasi (ada yang sedikit ada yang cukup dominan). Pendekatan proses yang dilakukan dalam penulisan tugas akhir berhasil mengidentifikasi sejumlah jenis plagiarisme dan mempublikasikan solusi terbaik untuk mengantisipasi tindakan negatif tersebut. Sejumlah jenis plagiarisme karya tulis tersebut antara lain adalah: a) duplikasi judul; b) duplikasi substansi; c) duplikasi kajian teori; d) duplikasi data/objek; e) penyandaran referensi palsu, dan atau duplikasi referensi. Tindak plagiarisme yang berbentuk duplikasi menunjukkan kesadaran mahasiswa untuk menjunjung nilai orisinalitas masih rendah. Semangat yang berkembang dalam kasus ini berkutat pada keinginan agar lebih mudah, lebih cepat, dan tidak mau terlalu sulit dalam menyelesaikan tugas akhirnya. Di samping itu, duplikasi belum dianggap sebagai tindakan negatif yang perlu dihindari oleh semua orang. Upaya penekanan dan pencegahan tindak plagiarisme skripsi merupakan salah satu pengembangan ke arah character building di dunia akademik yang sangat penting. Upaya pengendalian tindak plagiarisme tugas akhir skripsi antara lain adalah mengembalikan usulan, menyertakan referensi primer, dan merevisi total dan atau mengganti karya tulis tersebut. Pendekatan proses yang dilakukan telah berhasil menyodorkan solusi agar gejala plagiarisme tugas akhir tidak berkembang. Penyelesaiannya 
juga bertahap, yaitu: (1) mengidentifikasi gejala duplikasi tugas akhir; (2) membahas gejala duplikasi tersebut dengan anggota tim tugas akhir skripsi Prodi; (3) membicarakan gejala duplikasi tersebut dengan mahasiswa bersangkutan; (4) mengembalikan proposal dengan menunjukkan kemiripannya dengan karya tulis lain; (5) pada tindakan selanjutnya, mahasiswa harus memperbaiki dan atau mengganti skripsinya.

\section{DAFTAR PUSTAKA}

Arifin,E.Zaenal. 2004. Dasar-dasar Penulisan Karangan Ilmiah. Jakarta: PT. Grasindo.

Hartinah, Sri, penulisan karya ilmiah bagi pustakawan, makalah disampaikan pada diklat Alih ajar se provinsi jawa tengah, hal 2 dalam Hendry soelistyo, 2011, PLAGIARISME : pelanggaran hak cipta dan etika, yogyakarta : KANISIUS

Moeliono, Anton M. Ed. 2001. Kamus Besar Bahasa Indonesia. Jakarta: PT Gramedia

Panduan Penulisan Skripsi 2018, STIE Jambi

Peraturan Menteri Pendidikan Nasional R1 No. 17 Tahun 2010 Tentang Pencegahan dan Penanggulangan Plagiat di Perguruan Tinggi

Putra, Masri Sareb. 2011. Kiat Menghingdari Plagiat, How to Avoid Plagiarism. Jakarta: Indeks

Pasha, Teuku kemal, plagiat dan kegersangan perguruan tinggi, kompas, edisi 19 pebruari 2010 dalam Hendry soelistyo, 2011, PLAGIARISME : pelanggaran hak cipta dan etika, yogyakarta : KANISIUS

Rachmad, Edy. 2010. Fenomena Plagiarisme di Kampus. Jurnal Waspada Medan.

Soelistyo, Hendry, 2011, PLAGIARISME : pelanggaran hak cipta dan etika, yogyakarta : KANISIUS

Widyopramono, 1992, TINDAK PIDANA HAK CIPTA: analisis dan penyelesaianya, Jakarta: Sinar Grafika. 